\title{
Protein Deprivation from the Neonatal Period Impairs Lung Development in the Rat
}

\author{
MASENDU KALENGA' AND JEAN-CLAUDE HENQUIN \\ Unité de Diabétologie et Nutrition, University of Louvain Faculty of Medicine, Brussels, Belgium
}

\begin{abstract}
The effects of early protein-deficiency on lung development were studied in the rat. Newborn male rats were nursed in groups of eight. Control dams and pups received a $15 \%$ protein diet during the whole experiment. Test mothers only received 12 and $8 \%$ proteins from the 7 th and the 14th day of lactation. Test rats fed a diet of $8 \%$ protein were weaned at 21 days and maintained on the low protein diet for 1 month. This caused a marked decrease in body weight gain, but lung/body weight ratio was not affected. Lung DNA and protein content, lung protein concentration, but not lung DNA concentration were decreased, suggesting the presence of fewer and smaller cells than in control lungs. Volume-pressure curves were performed on excised lungs. With air-filling, the curve obtained in rats fed a diet with $8 \%$ proteins was shifted downward and to the right, even when expressed as percent of maximal volume. Its exponential analysis assessed a decrease in lung compliance. In contrast, with saline-filling, the recoil pressure was decreased in rats fed a diet with $8 \%$ proteins. Both with air and saline-filling, the pressure at lung rupture was increased in malnourished rats. It is concluded that protein-deficiency from the neonatal period increases surface forces, decreases tissue elastic forces, and augments resistance of the lung to rupture. (Pediatr Res 21: 45-49, 1987)
\end{abstract}

\section{Abbreviations}

V-P, volume-pressure

(P 15) rats, rats fed a diet with $15 \%$ proteins

(P 8) rats, rats fed a diet with $8 \%$ proteins

$V_{R P}$, volume at the point of lung rupture

$\mathbf{P}_{\mathrm{RP}}$, pressure at the point of lung rupture

$V_{30}$, air volume at a pressure of $30 \mathrm{~cm} \mathrm{H}_{2} \mathrm{O}$

$V_{10}$, saline volume at a pressure of $10 \mathrm{~cm} \mathrm{H}_{2} \mathrm{O}$

Respiratory infections are frequent and often lethal in malnourished infants. However, little is known about the repercussions of protein-calorie malnutrition on the lung function in comparison with its effects on other organs $(1,2)$.

Several morphological and biochemical stages of lung development have been well characterized during the postnatal period in the rat (3-7). The first stage (between birth and 4 days) corresponds to lung expansion. The second stage (between 4 and 12-13 days) is associated with formation of new alveoli. The

Received November 4, 1986; accepted February 2, 1987.

Correspondence J. C. Henquin, M.D., Unité de Diabétologie et Nutrition, UCL 54.74. Avenue Hippocrate, 54, B-1200 Brussels, Belgium.

M.K. supported by a fellowship from the European Association for Cooperation (Brussels). J-C.H. is Maitre de Recherches from the Fonds National de la Recherche Scientifique, Brussels.

'Present address University Clinics, Department of Pediatrics, B.P. 123, Kinshasa 11, Zaire. third stage (between 13 and 20 days) corresponds to elastin accumulation. The fourth stage (between 20 and 40 days) is a period of equilibrated growth in which alveolar proliferation slows and surface area increases with lung volume. The functional changes occurring during this lung maturation have been characterized recently (6).

The purpose of this work was to study the influence of early protein deficiency on the development of lung mechanical properties. To this end, dams were fed a diet containing decreasing amounts of proteins during the $3 \mathrm{wk}$ of lactation, and the offspring was thereafter maintained on the low protein-diet for another $4 \mathrm{wk}$. V-P curves and resistance to rupture were established with air or saline on excised lungs. Protein and DNA content of the tissue were also measured.

\section{MATERIALS AND METHODS}

The control diet contained $15 \%$ proteins $(15 \%$ casein, $41.2 \%$ starch, $13.8 \%$ glucose, $17 \%$ cellulose, $5 \%$ corn oil, and $8 \%$ vitamins and minerals). Test diets contained 12 or $8 \%$ proteins, but their carbohydrate content was increased to keep them isocaloric.

Pathogen-free male Wistar rats were obtained on the first postnatal day and nursed in groups of eight. Control mothers were fed the $15 \%$ protein diet for the $3 \mathrm{wk}$ of lactation, and the control offspring (P 15) were thereafter maintained on that same control diet. Test mothers received a diet with 15,12 , and $8 \%$ proteins during the $1 \mathrm{st}, 2 \mathrm{nd}$, and $3 \mathrm{rd}$ wk of lactation, respectively. Test rats (P 8) were then maintained on that low protein diet $(8 \%)$ until the age of 49 days. After weaning all rats were housed in groups of four per cage, except between 35-42 days of age, when they were placed in individual metabolic cages permitting daily measurement of food intake. Four weeks later (at the age of 49 days) the animals were anaesthetized with sodium pentobarbital ( $4 \mathrm{mg} / 100 \mathrm{~g}$ body weight) and exsanguinated by section of the trunk vessels. The trachea was exposed and cannulated just below the larynx with a plastic catheter. The lungs were then excised as described previously (8) and degassed for $2.5 \mathrm{~min}$ in a vacuum dessicator.

The tracheal cannula was connected via a $T$ tube to a peristaltic pump (LKB 1200, Bromma, Sweden) and an electromanometer (Philips XM 5321/00, containing a Statham pressure transducer P23 Db). Pressure was recorded on a strip-chart recorder (IFELEC 4000, Paris, France). The lungs were then continuously inflated and deflated (three complete cycles) either with air or with saline. With air the flow rate of the pump was $7 \mathrm{ml} / \mathrm{min}$ and the pressure varied between 0 and $30 \mathrm{~cm} \mathrm{H}_{2} \mathrm{O}$. With saline the flow rate was $4 \mathrm{ml} / \mathrm{min}$ and the pressure varied between 0 and $10 \mathrm{~cm} \mathrm{H}_{2} \mathrm{O}$. On a fourth inflation lungs were filled to the point of rupture. $V_{R P}$ and $P_{R P}$ were determined on the recording when the pressure curve showed a sudden change in its slope. When saline was used, the lungs were not immersed in fluid, but filled in horizontal position.

V-P curves were constructed from time pressure recordings by 
selecting 11 and 9 pressure levels for air and saline fillings, respectively. All measurements were made on the third deflation limb. Maximal lung volume was taken as the volume required to inflate the degassed lungs to a pressure of $30 \mathrm{~cm} \mathrm{H}_{2} \mathrm{O}$ with air or $10 \mathrm{~cm} \mathrm{H}_{2} \mathrm{O}$ with saline. V-P curves were plotted with volume expressed in absolute terms (in ml), and as percent of $V_{30}$ or $V_{10}$. These V-P curves were analyzed by an exponential function to calculate the lung compliance according to the method of Salazar and Knowles (9) as modified by Gibson et al. (10). The equation used was

$$
\mathrm{V}=\mathrm{Vmax}-\left(\mathrm{V} \max -\mathrm{V}_{0}\right) \mathrm{e}^{-\mathrm{kP}}
$$

were $\mathrm{V}$ is the lung volume at a transpulmonary pressure $\mathrm{P}, \mathrm{Vmax}$ is the maximal lung volume as defined above, and $V_{0}$ is the volume at $\mathrm{P}=0$. The lung compliance is assessed by the shape constant $\mathrm{k}$ of the exponential curve. From $\mathrm{V}$ and $\mathrm{P}$ values the best-fit, according to $\chi^{2}$ criterion, was obtained using an iterative exponential regression routine.

After completion of the mechanical tests with air, the lungs were carefully dissected from extrapulmonary airways and vessels, blotted dry, and weighed. The ratio of dry to wet weights was determined by weighing the left lobe before and after drying in an oven at $60^{\circ} \mathrm{C}$. The right lobe was homogenized in ice-cold $0.3 \mathrm{M}$ sucrose $(10 \% \mathrm{w} / \mathrm{v})$ buffered at $\mathrm{pH} 7.4$ with $3 \mathrm{mM}$ imidazole- $\mathrm{HCl}$. The livers were homogenized by the same method. The protein content of these homogenates and of the serum was measured (11) with bovine serum albumin as standard. DNA content of the homogenates was determined by fluorometry (12), using calf thymus DNA as standard.

Results are presented as means \pm SEM. Statistical significance of differences between control and test groups was assessed by the two-3tailed Student's $t$ test for unpaired values.

\section{RESULTS}

Nutritional studies. On the day of weaning the average body weight of the rats fed by a mother receiving a protein-restricted diet was significantly lower $(39 \pm 1 \mathrm{~g}, p<0.001, n=24)$ than that of the rats fed by a mother on a control diet $(48 \pm 1 \mathrm{~g})$. As shown by Figure 1, the body weight gain during the following 4 wk was markedly smaller in these protein-deficient rats than in controls. At the age of 49 days, the average body weight was only $99 \pm 2 \mathrm{~g}$ in (P 8) rats as compared to $174 \pm 3 \mathrm{~g}$ (P 15) rats. Rats fed a low protein diet consumed about $30 \%$ less calories than controls, so that their actual protein intake was reduced by $65 \%$ (Table 1). Their growth retardation was associated with a better protein-efficiency ratio, but with a clear decrease in the effective-

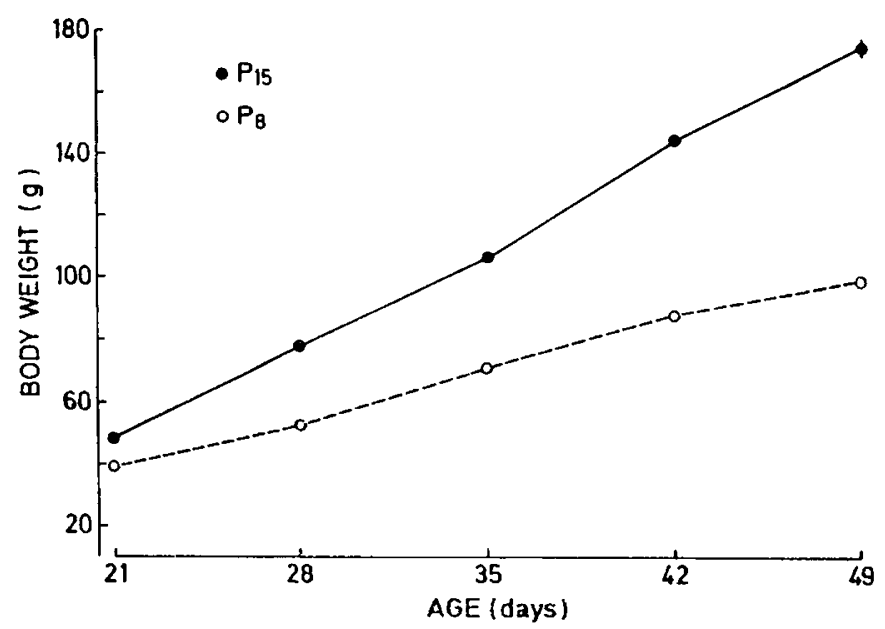

Fig. 1. Body weight of the rats fed a control diet (P 15) or a low protein diet (P 8). Values are means \pm SEM (usually within the size of the symbols) for 24 rats in each group.
Table 1. Food consumption and body wt gain by the rats fed a control $(P 15)$ or a low protein diet $(P 8)^{*}$

\begin{tabular}{lll}
\hline & (P 15) rats & \multicolumn{1}{c}{$(\mathrm{P} 8)$ rats } \\
\hline Daily caloric intake $(\mathrm{kcal})$ & $69.2 \pm 0.6$ & $47.2 \pm 0.9 \dagger$ \\
Daily protein intake $(\mathrm{g})$ & $2.64 \pm 0.02$ & $0.97 \pm 0.02 \dagger$ \\
Wt gain & & \\
g/day & $5.36 \pm 0.10$ & $2.39 \pm 0.07 \dagger$ \\
g/100 kcal & $7.76 \pm 0.15$ & $5.04 \pm 0.16 \dagger$ \\
g/g proteins & $2.01 \pm 0.02$ & $2.40 \pm 0.16 \ddagger$ \\
\hline
\end{tabular}

* Rats were housed in individual metabolic cages for 7 days (35-42 days of age). Measurements were made daily and are given as the average for the last 6 days. The first days thus served as adaptation to the new housing conditions. Values are means \pm SEM for 24 rats in each group.

$\dagger p<0.001$ vs rats receiving the control diet ( $\mathrm{P} 15)$.

$\ddagger p<0.005$ vs rats receiving the control diet (P 15).

ness of the ingested calories (Table 1). Total serum proteins were lower $(p<0.001)$ in (P 8) rats $(44.1 \pm 3.3 \mathrm{~g} / \mathrm{l})$ than in (P 15) rats $(54.9 \pm 3.9 \mathrm{~g} / \mathrm{l})$.

Biochemical studies. Table 2 summarizes the biochemical characteristics of the lungs. Protein-deficiency resulted in lung growth retardation as evidenced by a low lung weight $(61.6 \%$ of controls). However, lung weight was normal relative to body weight, and the dry/wet weight ratio was not altered. Total lung DNA was decreased, but DNA concentration was unchanged. Total lung proteins were decreased by about $50 \%$ and their concentration per $g$ of lung or per mg DNA remained lower than in control rats. The liver of these animals was also analyzed for comparison (Table 2). Absolute, but not relative, weight of the liver was decreased in protein-deficient rats. DNA and proteins were decreased to the same extent as in the lungs.

$V$-P studies. A complete sequence of three air V-P curves could be performed in $8 / 15(\mathrm{P} 15)$ rats and $10 / 14(\mathrm{P} 8)$ rats. $\mathrm{V}_{30}$ was decreased in protein-deficient rats (Fig 2, left). However, $\mathrm{V}_{30} / \mathrm{g}$ of lung was similar in the two groups: $9.5 \pm 0.3$ and $9.2 \pm 0.3$ $\mathrm{ml} / \mathrm{g}$ in $(\mathrm{P} 15)$ and $(\mathrm{P} 8)$ rats, respectively. Lungs of $(\mathrm{P} 8)$ rats contained significantly smaller volumes of air at all transpulmonary pressure levels (Fig. 2, left). When the volume of air was expressed as percentage of $V_{30}$, the V-P curve of $(P$ 8) rats was significantly shifted downward and to the right (Fig. 2, right). This indicates a decrease in lung compliance that could be quantitated by the shape constant $\mathrm{k}\left(\mathrm{cm} \mathrm{H}_{2} \mathrm{O}^{-1}\right)$ of the exponential function fitting these curves: $0.378 \pm 0.018$ in $(\mathrm{P} \mathrm{15})$ rats and $0.251 \pm 0.013$ in $(\mathrm{P} 8)$ rats $(\mathrm{p}<0.001)$. Relative volume of trapped air at $0 \mathrm{~cm} \mathrm{H}_{2} \mathrm{O}$ was lower in (P 8) rats $(2.3 \pm 0.2 \mathrm{ml} / \mathrm{g}$ tissue) than in (P 15) rats $(3.1 \pm 0.1 \mathrm{ml} / \mathrm{g} ; p<0.05)$.

Lung volumes and pressures at the point of rupture, recorded during a 4th air-inflation, are presented in Table 3. Absolute $V_{R P}$, but not relative $V_{R P}$ (per $g$ lung), was decreased in proteindeficient rats whereas $P_{R P}$ was increased.

A complete sequence of three saline V-P curves could be performed in $8 / 9(P 15)$ rats and in $9 / 10$ (P 8) rats. $V_{10}$ was decreased in protein-deficient rats (Fig. 3, left). However, $\mathrm{V}_{10} / \mathrm{g}$ of lung was similar in the two groups: $10.0 \pm 0.4 \mathrm{ml} / \mathrm{g}$ and 9.2 $\pm 0.3 \mathrm{ml} / \mathrm{g}$ in (P 15) and (P 8) rats, respectively. Lungs of (P 8) rats contained significantly smaller volumes of saline at almost all transpulmonary pressure levels (Fig. 3, left). When the volume of saline was expressed as percentage of $V_{10}$, the V-P curve of $(P$ 8) rats was significantly shifted upward and to the left over a wide range of pressures (Fig. 3, right). These curves obtained after saline filling could not be fitted by an exponential function, but tended to be sigmoidal. Relative volume of trapped saline at $0 \mathrm{~cm} \mathrm{H}_{2} \mathrm{O}$ was higher in $(\mathrm{P} 8)$ rats $(3.2 \pm 0.2 \mathrm{ml} / \mathrm{g}$ tissue $)$ than in $(\mathrm{P} 15)$ rats $(2.4 \pm 0.2 \mathrm{ml} / \mathrm{g} ; p<0.025)$.

During a 4 th cycle of saline inflation, absolute $V_{R P}$, but not relative $V_{R P}$ (per $g$ lung) was decreased in protein-deficient rats, whereas $P_{R P}$ was significantly higher than in controls (Table 3). 
Table 2. Biochemical characteristics of the lungs and liver of rats fed control $(P 15)$ or low protein diet $(P 8)^{*}$

\begin{tabular}{|c|c|c|}
\hline & (P 15) rats & (P 8) rats \\
\hline \multicolumn{3}{|l|}{ Lung wt } \\
\hline Wet $(g)$ & $0.86 \pm 0.02$ & $0.53 \pm 0.01 \dagger$ \\
\hline Wet (\% body wt) & $0.50 \pm 0.01$ & $0.52 \pm 0.01$ \\
\hline Dry/wet (\%) & $21.4 \pm 0.1$ & $21.0 \pm 0.2$ \\
\hline \multicolumn{3}{|l|}{ Lung DNA content } \\
\hline $\mathrm{Mg} /$ lung & $5.20 \pm 0.14$ & $3.14 \pm 0.10 \dagger$ \\
\hline $\mathrm{Mg} / \mathrm{g}$ lung & $6.10 \pm 0.15$ & $5.98 \pm 0.16$ \\
\hline \multicolumn{3}{|l|}{ Lung protein content } \\
\hline $\mathrm{Mg}$ /lung & $91.8 \pm 2.8$ & $42.9 \pm 1.2 \dagger$ \\
\hline $\mathrm{Mg} / \mathrm{g}$ lung & $107 \pm 2.8$ & $81.6 \pm 1.4 \dagger$ \\
\hline $\mathrm{Mg} / \mathrm{mg}$ DNA & $17.1 \pm 0.5$ & $13.7 \pm 0.3 \dagger$ \\
\hline \multicolumn{3}{|l|}{ Liver wt } \\
\hline Wet $(g)$ & $7.33 \pm 0.15$ & $4.31 \pm 0.14 \dagger$ \\
\hline Wet (\% body wt) & $4.18 \pm 0.06$ & $4.26 \pm 0.09$ \\
\hline \multicolumn{3}{|l|}{ Liver DNA content } \\
\hline $\mathrm{Mg} /$ liver & $29.5 \pm 0.7$ & $16.1 \pm 0.4 \dagger$ \\
\hline $\mathrm{Mg} / \mathrm{g}$ liver & $4.02 \pm 0.10$ & $3.81 \pm 0.11$ \\
\hline \multicolumn{3}{|l|}{ Liver protein content } \\
\hline $\mathrm{Mg}$ /liver & $1262 \pm 20$ & $632 \pm 21 \dagger$ \\
\hline $\mathrm{Mg} / \mathrm{g}$ liver & $173 \pm 2.7$ & $147 \pm 1.5 \dagger$ \\
\hline $\mathrm{Mg} / \mathrm{mg}$ DNA & $43.4 \pm 0.9$ & $39.3 \pm 1.1 \ddagger$ \\
\hline
\end{tabular}

* Values are means \pm SEM for 15 (P 15) and eight (P 8) rats for lung measurements and for 24 rats for liver measurements.

$\dagger p<0.001$ vs control rats.

$\ddagger p<0.005$ vs control rats.

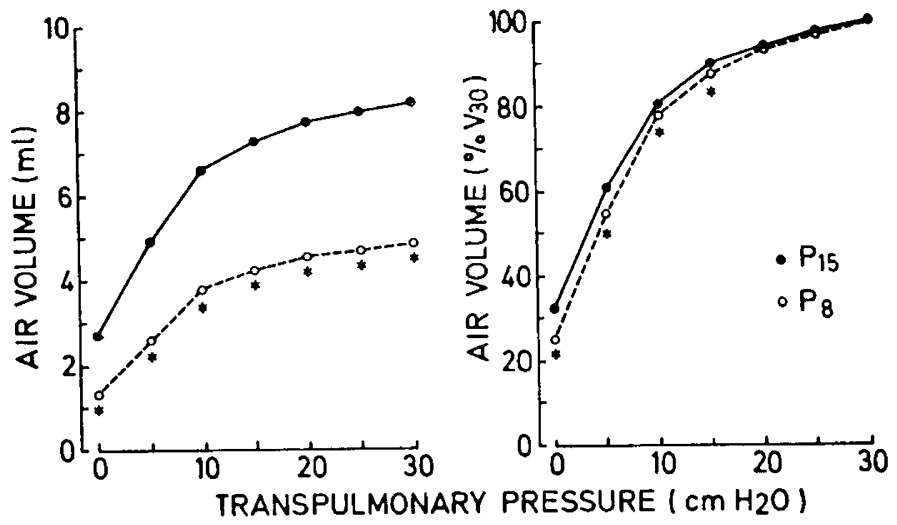

Fig. 2. Deflation V-P curves determined in air-filled lungs of rats fed a control diet (P 15) or a low protein diet (P 8). Volumes are expressed in absolute terms (left) or as percentage of $\mathrm{V}_{30}$. Values are means for eight (P 15) or 10 (P 8) rats (SEM were within the size of the symbols). $* p<0.05$ or less from controls.

\section{DISCUSSION}

Postnatal malnutrition in rats is usually induced by increasing the number of pups suckling a single mother (13). In the present study we attempted to induce a predominant protein deprivation by a progressive decrease in the protein content of the diet given to the mother and subsequent administration of the same low protein diet to the weaned rats. This caused growth retardation present at weaning and marked decrease in body weight gain thereafter. Daily measurements of food consumption by these animals revealed that the model leads to a mixed protein-calorie deprivation with predominant protein deficiency. As previously observed (14) such a situation was accompanied by a decrease in calorie efficiency and an increase in protein efficiency.

In these rats whose malnutrition started before weaning, lung growth was decreased in proportion to ponderal retardation. Taking DNA content of the tissue as an index of cell number
Table 3. $V_{\mathrm{RP}}$ and $P_{\mathrm{RP}}$ of lung rupture during air or saline inflation in rats fed control $(P 15)$ or low protein diet $(P 8)^{*}$

\begin{tabular}{ccc}
\hline & $(\mathrm{P} 15)$ rats & \multicolumn{1}{c}{$(\mathrm{P} \mathrm{8})$ rats } \\
\hline Air inflation $(n)$ & $(8)$ & $(10)$ \\
$\mathrm{V}_{\mathrm{RP}}(\mathrm{ml})$ & $10.9 \pm 0.5$ & $6.6 \pm 0.2 \dagger$ \\
$\mathrm{V}_{\mathrm{RP}}(\mathrm{mg} / \mathrm{g}$ lung $)$ & $12.6 \pm 0.5$ & $12.6 \pm 0.4$ \\
$\mathrm{P}_{\mathrm{RP}}(\mathrm{cm} \mathrm{H} \mathrm{O})$ & $50.8 \pm 3.3$ & $60.2 \pm 2.7 \ddagger$
\end{tabular}

Saline inflation $(n)$
$\mathrm{V}_{\mathrm{RP}}(\mathrm{ml})$
$\mathrm{V}_{\mathrm{RP}}(\mathrm{ml} / \mathrm{g}$ lung $)$
$\mathrm{P}_{\mathrm{RP}}\left(\mathrm{cm} \mathrm{H} \mathrm{H}_{2} \mathrm{O}\right)$

$11.3 \pm 0.4$

$13.6 \pm 0.4$

$18.5 \pm 1.7$

(9)

$\begin{aligned} 6.6 & \pm 0.3 \dagger \\ 12.4 & \pm 0.5 \\ 23.6 & \pm 1.3 \ddagger\end{aligned}$

* Since the wet weight of the lungs could not be accurately determined after saline inflation, the average wet weight obtained after air inflation was used to calculate $\mathrm{V}_{\mathrm{RP}}$ in $\mathrm{ml} / \mathrm{g}$ wet weight. Values are means $\pm \mathrm{SEM}$ for $(n)$ rats.

$\dagger p<0.001$ vs rats receiving the control diet (P 15).

$\ddagger p<0.05$ vs rats receiving the control diet (P 15).
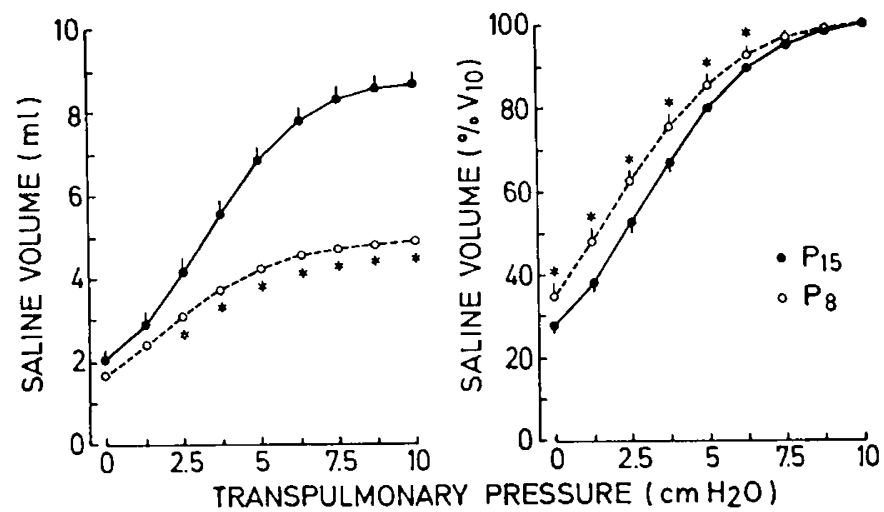

Fig. 3. Deflation V-P curves determined in saline-filled lungs of rats fed a control diet (P 15) or a low protein $\operatorname{diet}(\mathrm{P} 8)$. Volumes are expressed in absolute terms (left) or as percentage of $\mathrm{V}_{10}$. Values are means $\pm \mathrm{SEM}$ for eight (P 15) or nine (P 8) rats. ${ }^{*} p<0.05$ or less from controls.

and the protein/DNA ratio as an index of cell size (15), it appears that these lungs contained fewer cells than control lungs and that these cells were of smaller size. The estimated decrease in cell number was more pronounced than in the lungs of rats submitted to calorie or protein deprivation from the age of $21-28$ days only $(8,16)$. This may reflect impairment of lung cell division that is most important before the age of 21 days $(3,15)$. Our interpretation is supported by the observation that protein-calorie deprivation, whether started before (this study) or after weaning (8), caused a similar decrease in DNA content of the liver, an organ where cell division continues at about the same rate until the age of 45 days (15).

To ensure optimal uniformity and reproducibility of volume and pressure changes in the lungs, a technique of continuous inflation-deflation was used. To evaluate the relative contributions of surface and tissue elastic forces, V-P curves were performed both with air and saline filling $(17,18)$. Protein restriction differently altered V-P curves with air or saline filling when these were expressed as percent of maximal lung volume to account for differences in lung size. After air filling, the curve was shifted downward and to the right, and a decrease in lung compliance, assessed by the shape constant $\mathrm{k}$ of the exponential function fitted to the P-V curve, was calculated. In contrast, after salinefilling the curve was shifted upward and to the left, the recoil pressure being decreased at almost all volumes.

To our knowledge only one study, published in abstract form (19), has evaluated the repercussions of early malnutrition on 
the lung function in the rat. Malnutrition was induced by allowing 18 pups to suckle a single mother. At 21 days, a left shift of the V-P curve obtained with saline filling was observed, as in our study, but no alteration was seen in the V-P curve obtained with air filling. The reason of this discrepancy is difficult to appreciate from an abstract.

The alterations in lung mechanics described herein somewhat differ from those induced by a malnutrition starting at 21-28 days $(8,20,21)$. Opposite shifts of the air and saline V-P curves, as produced herein by malnutrition starting before weaning, were not induced by food deprivation in weaned rats. In two studies, a decrease in lung compliance was measured in air- or salinefilled lungs $(8,20)$ whereas a trend to lower recoil pressures at low volumes was reported in the third study (21).

As proposed to explain the complex alterations in lung mechanics occurring in starved adult rats (22), we suggest that malnutrition starting during the suckling period affects both surface and tissue elastic forces of the lungs. On the one hand, an increase in surface forces, due to impaired production of surfactant or alteration of surfactant quality, could explain the decrease in compliance evidenced after air inflation. Thus, low concentrations of surfactant have been measured in the lungs of malnourished suckling (23), weanling (16), young (24), and adult $(25,26)$ rats. Similar observations were also made in rats $(27)$ or guinea pigs (28) just born $(<10 \mathrm{~h})$ to mothers that were malnourished during gestation. This fall in surfactant concentration was accompanied by an increase in minimal surface tension of lung extracts from newborn rats (27), but did not alter V-P characteristics of air-filled lungs in guinea pigs (28). Although species differences can contribute to the discrepancy between this latter study (28) and the present one, the period of malnutrition (prenatal and postnatal) and its duration are certainly of importance. In this respect, it should be noted that the concentration of total surfactant phospholipids rapidly falls during starvation in young and adult rats $(16,24-26)$, but that an increase in surface forces can be evidenced only when food deprivation is maintained for relatively long periods $(8,20,21)$. Changes in surfactant quality, and not only quantity, may be involved.

On the other hand, a decrease in tissue elastic forces could explain the decrease in recoil pressure after saline infusion, an observation also made in guinea pigs submitted to prenatal starvation (28). Since lung elasticity is mainly due to elastin (29), and since elastin deposition essentially takes place before the age of 1 month (6), our observations could be accounted for by an alteration of this deposition during early malnutrition. This interpretation is directly supported by the histological demonstration of a decrease in lung elastin in two models of rats submitted to starvation during the suckling period $(30,31)$. It is also consistent with our previous observation (8) that no such decrease in recoil pressure after saline inflation was recorded in young rats submitted to protein-calorie restriction from the age of 28 days only.

The pressure at lung rupture was higher in protein-deficient rats than in controls. As this difference persisted during saline filling, it is unlikely to be secondary to changes in surface forces only. In normal rats, resistance of the lungs to rupture by saline inflation increases with collagen concentration of the tissue (6). Total collagen content decreases, but collagen concentration slightly increases in the lungs of malnourished rats when food restriction is started after weaning $(21)$ or in adulthood $(32,33)$. It is possible that early protein deficiency causes desequilibrated growth of the lungs with a similar increase in collagen proportion or alters collagen properties in the lungs as in other tissues (34).

In conclusion, protein deprivation from the neonatal period impaired lung growth and altered lung mechanical properties in the rat. Opposite shifts of the V-P curves obtained after air or saline filling suggest an increase in surface forces and a decrease in tissue elastic recoil, possibly due to deficits in surfactant and elastin, respectively. An increase in lung resistance to rupture after saline filling also suggests alterations in collagen amount or properties. The mixed protein-calorie deprivation with predominant protein deficiency imposed on our rats was not extreme and is frequently encountered in developing countries. Our results therefore suggest that alterations of lung development may have to be added to the list of the functional consequences of protein-calorie malnutrition in children.

Acknowledgments. The authors gratefully acknowledge the continuous interest and support of Prof. R. De Meyer (Brussels) and the helpful advice and suggestions of Prof. C. Gaultier (Paris) during the course of these studies, as well as their critical reading of the manuscript. They also thank Prof. J. Tremouroux for lending equipment and Mrs. M. Detaille for editorial help.

\section{REFERENCES}

1. Wilson DO, Rogers RM, Hoffman RM 1985 Nutrition and chronic lung disease. Am Rev Respir Dis 132:1347-1365

2. Frenk S 1985 Protein-energy malnutrition. In: Arneil GC, Metcoff J (eds) Pediatric nutrition. Butterworths, London, pp 153-193

3. Burri PH 1974 The postnatal growth of the rat lung. III. Morphology. Anat Rec 180:77-98

4. Burri PH, Dbaly J, Weibel ER 1974 The postnatal growth of the rat lung. I. Morphometry. Anat Rec 178:711-730

5. Powell JT, Whitney PL 1980 Postnatal development of rat lung. Changes in lung lectin, elastin, acetylcholinesterase and other enzymes. Biochem $\mathrm{J}$ 188:1-8

6. Nardell EA, Brody JS 1982 Determinants of mechanical properties of rat lung during postnatal development. J Appl Physiol 53:140-148

7. Vaccaro C, Brody JS 1978 Ultrastructure of developing alveoli. I. The role of the interstitial fibroblast. Anat Rec 192:467-480

8. Kalenga M, Henquin JC 1987 Alteration of lung mechanics by protein-calorie malnutrition in weaned rats. Respir Physiol (in press)

9. Salazar E, Knowles JH 1964 An analysis of pressure-volume characteristics of the lung. J Appl Physiol 19:97-104

10. Gibson GS, Pride NB, Davis J, Schroter RC 1979 Exponential description of the static pressure-volume of normal and diseased lungs. Am Rev Respir Dis 120:799-811

11. Lowry OH, Rosebrough NJ, Farr HL, Randall RJ 1951 Protein measurement with the folin phenol reagent. J Biol Chem 193:265-275

12. Karsten U, Wollenberger A 1977 Improvements in the ethidium bromide method for direct fluorometric estimation of DNA and RNA in cell and tissue homogenates. Anal Biochem 77:464-470

13. Widdowson EM, McCance FRS 1960 Some effects of accelerating growth. I. General somatic development. Proc R Soc Lond [Biol] 152:188-206

14. Phillips LS 1981 Nutrition, metabolism and growth. In: Daughaday WH (ed) Endocrine Control of Growth. Elsevier, New York, pp 121-173

15. Winick M, Noble A 1965 Quantitative changes in DNA, RNA, and protein during prenatal and postnatal growth in the rat. Dev Biol 12:451-466

16. Gross I, Ilic I, Wilson CM, Rooney SA 1976 The influence of postnatal nutritional deprivation on the phospholipid content of developing rat lung. Biochim Biophys Acta 441:412-422

17. Mead J 1961 Mechanical properties of lungs. Physiol Rev 41:281-330

18. Forrest JB 1976 Lung tissue plasticity: morphometric analysis of anisotropic strain in liquid filled lungs. Respir Physiol 27:233-239

19. Thibeault DW, Fulghum T 1981 The effect of postnatal malnutrition on rat lung development. Pediatr Res 15:732(abstr)

20. Myers BA, Dubick MA, Gerreits J, Rucker RB, Jackson AC, Reiser KM, Williams SM, Last JA 1983 Protein deficiency: effects on lung mechanics and the accumulation of collagen and elastin in rat lung. $J$ Nutr 113:23082315

21. Sahebjami H, MacGee J 1985 Effects of starvation on lung mechanics and biochemistry in young and old rats. J Appl Physiol 58:778-784

22. Sahebjami H, Vassalo CL, Wirman JA 1978 Lung mechanics and ultrastructure in prolonged starvation. Am Rev Respir Dis 117:77-83

23. Diop A, Tordet C, Marin L 1985 Influence de la sous-nutrition sur le développement pulmonaire post-natal chez le rat. In: Proceedings of the Meeting of the Groupe d'Études et de Recherches sur la Malnutrition, Brighton, p 23(abstr)

24. Gail DB, Massaro GD, Massaro D 1977 Influence of fasting on the lung. J Appl Physiol 42:88-92

25. Weiss HS, Jurrus E 1971 Starvation on compliance and surfactant of the rat lung. Respir Physiol 12:123-129

26. Sahebjami H, MacGee J 1982 Effects of starvation and refeeding on lung biochemistry in rats. Am Rev Respir Dis 126:483-487

27. Faridy EE 1975 Effect of maternal malnutrition on surface activity of fetal lungs in rats. J Appl Physiol 39:535-540

28. Lechner AJ, Winston DC, Bauman JE 1986 Lung mechanics, cellularity, and surfactant after prenatal starvation in guinea pigs. J Appl Physiol 60:16101614

29. Hance AJ, Crystal RG 1975 The connective tissue of lung. Am Rev Respir Dis 112:657-711 
30. Das RM 1984 The effects of intermittent starvation on lung development in suckling rats. Am J Pathol 117:326-332

31. Bruce MC, Pawlowski R. Tomashefski JF 1986 Influence of hyperoxic exposure and/or malnourishment on development of lung parenchyma and parenchymal elastin in young rats. Am Rev Respir Dis 113:A 186(abstr)

32. Harkema JR, Mauderly JL, Gregory RE, Pickrell JA 1985 A comparison of starvation and elastase models of emphysema in the rat. Am Rev Respir Dis
129:584-591

33. Kerr JS, Riley DJ, Lanza-Jacoby S, Berg RA, Spikler HC, Yu SY, Edelman NH 1985 Nutritional emphysema in the rat: influence of protein depletion and impaired lung growth. Am Rev Respir Dis 131:644-650

34. Anasuya A and Narasinga Rao BS 1970 Relationship between body collagen and urinary hydroxyproline excretion in young rats fed a low-protein or low calorie diet. Br J Nutr 24:97-107 